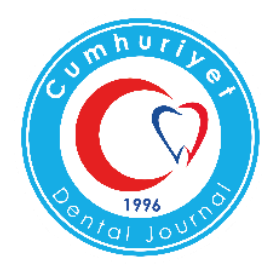

\title{
THE EFFECT OF DIODE LASER AS AN ADJUNCT TO PERIODONTAL TREATMENT ON CLINICAL PERIODONTAL PARAMETERS AND HALITOSIS: A RANDOMIZED CONTROLLED CLINICAL TRIAL
}

\author{
Periodontal Tedaviye Destek Olarak Kullanılan Diyot Lazerin Periodontal Klinik
} Parametrelere Ve Halitozis Üzerine Etkileri: Randomize Kontrollü Klinik Çalışma

\author{
Mükerrem HATIPOĞLU ${ }^{1}$, Zeliha AYTEKİN ${ }^{1}$, Özlem DALTABAN ${ }^{1}$, \\ Rasih FELEK ${ }^{1}$, Mehmet Ziya FIRAT ${ }^{2}$, Kemal ÜSTÜN ${ }^{1}$
}

$\begin{array}{ll}\text { Makale Kodu/Article Code } & : 148016 \\ \text { Makale Gönderilme Tarihi } & : 20.10 .2015 \\ \text { Kabul Tarihi } & : 24.02 .2017\end{array}$

\section{ABSTRACT}

Aim: The aim of this study is to examine the clinical efficiency of diode laser periodontal pocket irradiation as an adjunct to conventional scaling and root planning (SRP) on periodontal parameters and halitosis.

Material and Methods: In our randomized, controlled clinical trial, 40 patients with untreated chronic periodontitis were randomly separated into two group to receive SRP with laser (laser group $\mathrm{n}=20$ ) or SRP solely (control group $\mathrm{n}=20$ ). Plaque index (PI), gingival index (GI), probing pocket depth (PD), clinic attachment loss (CAL), bleeding on probing (BOP) and halitosis were recorded at baseline and 1st ,3rd and6th months after treatment by a periodontist.

Results: Both treatment methods showed significant reductions in clinical parameters and halitosis levels compared to baseline.

Conclusion: The present study indicates that compared to SRP solely, adjunctive applications of a 940-nm diode laser with SRP showed lower bleeding on probing and halitosis levels.

Key Words: Periodontitis, Diode Laser, Halitosis.

\section{ÖZ}

Amaç: Bu çalışmanın amacı geleneksel diş yüzeyi temizliği ve kök yüzeyi düzleştirmesine (SRP) ek olarak periodontal cep içerisine diyot lazer uygulamasının periodontal parametreler ve ağız kokusu üzerine klinik etkinliğini incelemektir. Materyal Metot: Randomize kontrollü klinik çalışmamızda, tedavi edilmemiş kronik periodontitisli 40 hasta rastgele SRP ve lazer uygulananlar (lazer grubu $n=20$ ) veya sadece SRP uygulananlar (kontrol grubu $\mathrm{n}=20$ ) olmak üzere iki gruba ayrıldı. Başlangıçta ve 1. 3. ve 6. aylarda plak indeksi (PI), gingival indeks (GI), cep derinliği (PD), klinik ataşman kaybı (CAL), sondalamada kanama (BOP) ve halitozis kaydedildi.

Bulgular: Her iki tedavi metodunda da klinik parametreler ve halitozis seviyeleri başlangıca göre anlamlı derecede azalma gösterdi.

Sonuç: $\mathrm{Bu}$ çalışma, yalnızca SRP'ye kıyasla SRP'ye ek olarak $940 \mathrm{~nm}$ diyot lazer uygulamasinda sondalamada kanama ve halitozis seviyelerinin daha düşük olduğunu göstermiştir.

Anahtar Kelimeler: Periodontitis, Diyot Lazer, Halitozis

\footnotetext{
${ }^{1}$ Department of Periodontology, Faculty of Dentistry, Akdeniz University, Antalya, Turkey

${ }^{2}$ Department of Animal Science, Biometry and Genetics, Faculty of Agriculture, Akdeniz University, Antalya, Turkey
} 


\section{INTRODUCTION}

Chronic periodontitis is an inflammatory disease which develops against the microbial plaque on tooth surface and ends in loss of periodontal tissues. ${ }^{1}$ The prime target in periodontal treatment is the elimination of all factors which cause formation and cumulation of the plaque. ${ }^{2}$

In nonsurgical periodontal treatment, infection is aimed to be controlled by mechanically removing supragingival and subgingival calculus. ${ }^{3}$ The success of periodontal treatment depends on totally removing subgingival and supragingival pathogens and enabling oral hygiene by the patient after the treatment. ${ }^{4,5}$

Tooth surface (SRP) is the most important procedure in the treatment of periodontitis and its clinical benefits were proved by many studies. ${ }^{4,}$ 6, 7 However, microbial component may not be removed totally by mechanical treatment in the presence of deep pockets. ${ }^{8}$ Therefore, many methods such as antibiotics, antiseptics and lasers have been used in addition to periodontal treatment. ${ }^{9-12}$

Dental laser usage has been commonly used recently. Different laser types are used for dental purposes such as Er:YAG laser, Er,Cr:YSGG laser, Nd:YAG laser, CO2 laser and diode laser. ${ }^{13,14}$

Diode laser is a semiconductor laser, which uses combinations of elements such as gallium $(\mathrm{Ga})$, arsenide (Ar), aluminum (Al) and indium (In) for the transformation of electric energy into luminous energy. ${ }^{15,16}$ Diode laser, which can be used in soft tissue implementations successfully, do not penetrate into hard tissues. ${ }^{13}$ Many studies showed that diode laser has an antibacterial activity when it is used to support periodontal treatment. ${ }^{17-19}$

Moritz et al. suggest that diode laser as an adjunct to SRP will decrease bacteria amount and inflammation. ${ }^{17}$ They achieved positive results in clinical parameters but irradiation procedure caused morphological changes on root surface. ${ }^{17,19}$

The term 'halitosis' means bad breath which can have local or systemic origins. ${ }^{20,21}$ 10 per cent of halitosis cases develop because of extra-oral reasons. ${ }^{22}$ Halitosis can be observed in people of different ages and negatively affect social interaction of the person. $^{23}$ Findings which belong to epidemiological studies in different countries cannot be compared because there are not standart protocols for treatment and diagnosis of halitosis. ${ }^{24}$

Most of extra oral factors which cause halitosis are generated from respiratory tract or otorhinolaryngologic diseases such as tonsillitis, sinusitis and post-nasal drip. Bad breath can occur rarely because of renal, hepatic, endocrinological or gastrointestinal reasons. ${ }^{22,24-27}$ The cumulated materials can be smelt by the breath within some certain systemic diseases such as acetone smell within diabetic patients or ammonia smell within urea or cirrhotic patients. ${ }^{28}$ Periodontal diseases, caries, bacteria plaque on the tongue, insufficient salivation, stomatitis, in-mouth neoplasm, extraction socket which is being treated and smelly food consumption are amongst in-mouth reasons of halitosis..$^{22,24,29}$

Volatile sulphur compounds (VSC) are formed as oral microorganisms which exist in saliva, periodontal pockets, tongue and other parts of the mouth proteolysate free amino aside substrates, such as cysteine, sistine and methionine which include sulphur. ${ }^{30}$ VSC is mainly composed of hydrogen sulfide, methyl mercaptan and dimethyl sulfide components which are the main reasons of bad breath. ${ }^{31,32}$

Two methods are implemented in the evaluation of halitosis; the first one is organoleptic method which is subjective. In this method, breath of the patient is graded through smelling by an educated and experienced person. The method can give variable values because it is a sense method 
besides it is not a good experience both for the patient and the implementer. ${ }^{38,} 39$ The second method is measuring VSC amount by gas chromatography or halimeter which is an objective method. ${ }^{40}$ When halitosis is measured by a halimeter, nano VSC amount can be defined. ${ }^{41-45}$ VSC amount within the people with periodontal diseases are more than healthy people because of the high rate of bacteria plaque covering the tongue. Therefore, there is a positive relation between the severity of periodontal disease and VSC content. ${ }^{31}$

The main principle in the treatment of halitosis is eliminating oral pathogens and restraining bacterial bio film. Many methods are adopted in order to treat halitosis such as using mouthwash solutions with CHX, hydrogen peroxide and essential oil, tongue scraper or tongue brush. 70 per cent of oral sulfides will be eliminated by tongue cleaning. ${ }^{46}$ Chewing gum with mint and mouth sprays is also used in order to cover the smell. ${ }^{21,24,47-51}$

Our study aims at evaluating the effectiveness of diode laser usage as an adjunct to SPR both on periodontal parameters and halitosis.

\section{MATERIAL AND METHOD}

Selection of the Participators and Design of the Study

This study is a randomized controlled clinical study. 40 adults (20 females, 20 males), who were selected from the patients without periodontal treatment in the last 6 months, who consulted to Akdeniz University Faculty of Dentistry Periodontology clinic between September 2014 and March 2015 for periodontal complaints or controls, were included in the study. All patient provided written permissions. The protocol of the study was approved by Antalya Training Research Hospital Non-pharmaceutical Clinic Researches Ethical Commission (2014 decision no:46/10).
The people who have systemic diseases, require regular medicine, are pregnant, smoke and people with fixed partial denture were not included in the study. The people have minimum 14 teeth and at least 2 teeth that have $5 \mathrm{~mm}$ pocket in each quadrant. The people were only divided into 2 random groups as the ones who have SRP treatment (control group KG $\mathrm{n}=20$ ) and who are implemented diode laser as an adjunct to SRP (Laser group $L G n=20$ )

\section{Halitosis measurement}

In our study halitosis measurements are done by Halimeter (InterscanCorp., Chatsworth, $\mathrm{Ca}$, USA). People were asked not to consume onion, garlic and spicy food and use mouthwash before the implementation day. People were also asked to breathe through the nose without opening their mouths for a minute then halimeter was placed into the mouth as not to touch the patient's tongue and palate.

\section{Clinical Procedure}

Plaque index (PI), gingival index (GI), clinical attachment level (CAL), probing pocket depth (PD), bleeding on probing (BOP) and halitosis measurements were carried out in 6 sections for each tooth after treatment prior to treatment of the patients.

SRP was implemented via hand pieces (Gracey Curettes, Hu-Friedy, Chicago, IL, USA) and ultrasonic equipment (EMS SA CH 1260 Nyon, SWITZERLAND). $940 \mathrm{~nm}$ indium-gallium-aluminum-phosphate diode lasers (Epic, Biolase, Irvine, CA, USA) were implemented in the same session under local anesthesia. Total $15 \mathrm{~J} / \mathrm{cm} 2$ power of laser in $1.5 \mathrm{~W}$ power with $20 \mathrm{~ms}$ frequency during 20 ms shots was implemented to periodontal pocket. Laser irradiation was realized with fiber optic ends which are of $300 \mu \mathrm{m}$ diameter. Fiber is implemented by parallelly locating on root surface level inside the periodontal pocket. Fiber laser is directed from apical to coronal during light emission. It was implemented in total 20 seconds as 10 second 
lingual to 10 seconds to each tooth in meziodistal direction in buccal angle. ${ }^{12}$

The patients were provided with detailed oral hygiene training at the end of the session. The training includes the usage of materials such as dental floss and interdental brush which are used for interdental cleaning and how to clean dorsum and lateral of tongue with brush and tongue cleaner.

Clinical index scores and halitosis levels were measured after 1,3 and 6 months after the treatment. The patients were not informed about their categories in the groups during the treatment.

Whether they correlate normal distribution or not is decided via ShapiroWilks test for statistical assessment of datum. Variance analysis, Tukey multiple comparison tests and independent sample t-test were carried out via an appropriate software for the assessment of datum which are defined to present normal distribution. (SPSS v20.0, IBM, Chicago, IL, USA).

\section{RESULTS}

Average and standard deviation values for datum of control group of clinical assessment criteria, the group which was implemented SRP solely and Diode laser group with combined SRP are presented in Table 1.

Table 1: Average and standard deviation results of datum of clinical evaluation criteria

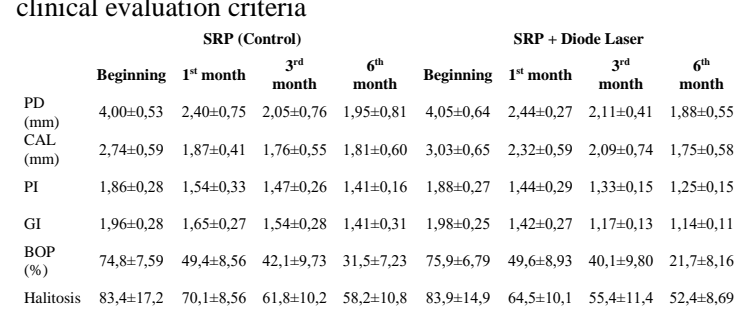

It was found out that both groups decreased pocket depth in time in the pocket depth (PD) measurement in clinical probing. However, in the statistical assessments a significant difference was not found between groups $(p>0.05)$. There was a decrease in both groups in the comparison of clinical attachment levels in $1^{\text {st }}, 3^{\text {rd }}$ and $6^{\text {th }}$ months. The difference between groups was found statistically significant especially in the $1^{\text {st }}$ month's measurement. It was shown in plaque index scores that both methods are effective related to time and plaque index values were decreased via the measurements in the beginning. It was found that the difference between SRP solely and diode laser combined with diode laser implementation were statictically significant in plaque index data in $3^{\text {rd }}$ and $6^{\text {th }}$ month periods. Both treatment methods were found effective in gingival index scores and statistically significant difference was found in the date which were held in the measurements in $1^{\text {st }}, 3^{\text {rd }}$ and $6^{\text {th }}$ months periods $(\mathrm{p}<0.05)$. As a result of data held with bleeding on probing, it was found that significant decrease was held especially at the end of $6^{\text {th }}$ month and the difference between groups in the data of these periods were significant. In halitosis measurements, it was discovered that both treatment methods decreased bad smell and there is a significant difference between treatment methods in $1^{\text {st }}, 3^{\text {rd }}$ and $6^{\text {th }}$ month's periods.

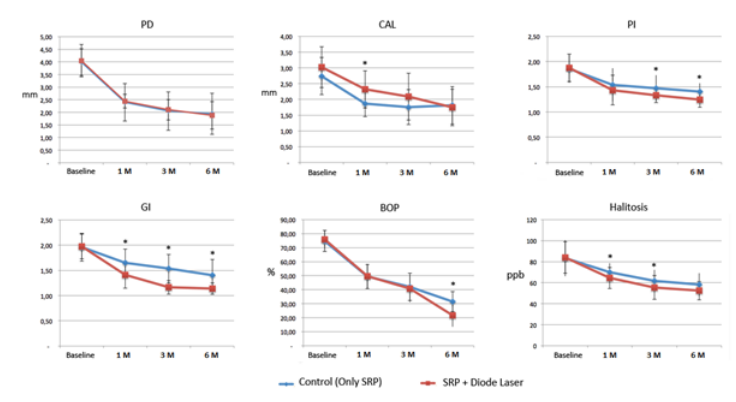

Figure 1: Datum of clinical evaluation criteria and statistical differences between groups. $(*: \mathrm{p}<0.05)$

\section{DISCUSSION}

There is much evidence on the benefits of nonsurgical treatment in the treatment of periodontal diseases. ${ }^{53}{ }^{54}$ It is argued that laser can be used as a support for non-surgical periodontal treatment. ${ }^{55}$ However, on the contrary, some authors decided that diode laser implementation combined with SRP has no 
supremacy over SRP implementation solely in terms of microbial parameters and gingival inflammation. ${ }^{56}, 57$ In our study, it was presented that both treatment prosedures caused significant recovery in clinical parameters.

Dukic and colleagues expressed that statistically significant recovery was held in clinical parameters in the group which they implemented SRP solely and the group implemented with diode laser combined with SRP in 6th and 18th weeks in a study, which was carried out on people with chronic periodontitis. $^{2}$

Aykol and colleagues achieved progress in periodontal pocket depth and bleeding on probing per cent in the group they implemented gallium-aluminum-arsenide after periodontal treatment in 1st, 2nd and 7th day through a similar study which they carried out with chronic periodontitis patients. ${ }^{58}$

Kreisler and colleagues implemented diode laser of $810 \mathrm{~nm}$ wave length to 2 random quadrants of the patients after they treated 22 patients with chronic periodontitis via routine SRP during their study. They presented that more statistically significant decrease was held in teeth mobility, pocket depth and clinical attachment loss in the tooth which were implemented laser when compared to control group. ${ }^{59}$

In our study CAL, BOP and PI datum were compared and decrease was found in both groups in $1^{\text {st }}, 3^{\text {rd }}$ and $6^{\text {th }}$ months. However, a statistically significant recovery was achieved in LG when compared to CG in the $1^{\text {st }}$ month's measurements. A statistically significant decrease was held in BOP measurements in LG when compared to CG in $6^{\text {th }}$ month.

Whilst probing pocket depth decreased in time in both groups in PD measurements a statistically significant difference cannot be found between groups.

Qadri and colleagues had better results in periodontal pocket depth, plaque index and gingival index in the areas where they implemented laser when they carried out a similar study design. ${ }^{60}$

Ustun and colleagues implemented diode laser of $810 \mathrm{~nm}$ wave length to 2 random quadrants of the patients after they treated 21 patients with chronic periodontitis via routine SRP during their study. CAL, BOP and PI datum were compared and decrease was found in both groups in $1^{\text {st }}, 3^{\text {rd }}$ and $6^{\text {th }}$ months. More decrease was achieved in LG when compared to CG in terms of PD levels in 1st, 3rd and 6th months. Better results were found in LG when compared to $\mathrm{CG}$ in terms of CAL and GI levels in $3^{\text {rd }}$ and $6^{\text {th }}$ months. They could not have found a statistically significant difference between two groups in terms of PI. ${ }^{61}$

PI and GI datum were compared and a decrease in both groups were found in our study. However, in all of $1^{\text {st }}, 3^{\text {rd }}$ and $6^{\text {th }}$ months' measurements in GI levels of LG had a statistically significantly decrease when compared to CG. Whilst decrease was observed in both groups within PI measurements, a statistically significant decrease was achieved in LG when compared to $C G$ in $3^{\text {rd }}$ and $6^{\text {th }}$ moths.

Many authors reported that periodontal disease is a significant reason of halitosis. ${ }^{62-65}$ Periodontal pathogens generate endotoxine, proteinase and VSC. Persson and colleagues stated that Bacteroides melaninogenicus, Treponema denticola, Porphyromonas gingivalis and Prevotella intermedia types produce VSC. ${ }^{66}$ VSC molecules, which are produced by gram negative bacteria on tongue and periodontal pocket, cause smell formation. ${ }^{67}$

A number of studies showed the positive relation between progression of periodontal disease and VSC amount. ${ }^{35}, 36$ Morita and Wang $^{68}$ found a significant relation between the severity of periodontal disease and VSC amount in breath. They discovered that VSC value was measured lower within people who 
are provided with periodontal treatment than the ones who are not treated. They also asserted that there is a correlation between VSC level and bleeding on probing and periodontal pocket depth. Coil and Tonzetich ${ }^{69}$ also found higher VSC levels in the people with deep pockets which bleed during probing than the people with shallow pockets with low bleeding rate during probing.

A similar relation between periodontitis and halitosis was also determined in our study. VSC level in $1^{\text {st }}, 3^{\mathrm{r}} \mathrm{d}$ and $6^{\text {th }}$ months were found to be lower than the first measured level in both groups which have periodontal treatment. Dissimilarly, VSC level which is measured in LG is found to be statistically significantly lower than $\mathrm{CG}$ in the $1^{\text {st }}$ and $3^{\text {rd }}$ months.

In the light of this information, we can state that laser treatment which is implemented as an adjunct to SRP has a statistically significant positive effect on clinical parameters and halitosis. In addition to that there is a need for new studies to discover in which mechanisms does laser effect these parameters.

\section{REFERENCES}

1. Armitage GC. Development of a classification system for periodontal diseases and conditions. Annals of periodontology / the American Academy of Periodontology. 1999; 4:1-6.

2. Dukic W, Bago I, Aurer A, Roguljic M. Clinical effectiveness of diode laser therapy as an adjunct to non-surgical periodontal treatment: a randomized clinical study. Journal of periodontology. 2013; 84:1111-7.

3. Kaldahl WB, Kalkwarf KL, Patil KD, Molvar MP, Dyer JK. Long-term evaluation of periodontal therapy: I. Response to 4 therapeutic modalities. Journal of periodontology. 1996; 67:93-102.

4. O'Leary TJ. The impact of research on scaling and root planing. Journal of periodontology. 1986; 57:69-75.
5. Cugini MA, Haffajee AD, Smith C, Kent RL, Jr., Socransky SS. The effect of scaling and root planing on the clinical and microbiological parameters of periodontal diseases: 12-month results. Journal of clinical periodontology. 2000; 27:30-6.

6. Lindhe J, Nyman S. Scaling and granulation tissue removal in periodontal therapy. Journal of clinical periodontology. 1985; 12:374-88.

7. Kaldahl WB, Johnson GK, Patil KD, Kalkwarf KL. Levels of cigarette consumption and response to periodontal therapy. Journal of periodontology. 1996; 67:675-81.

8. Sherman PR, Hutchens LH, Jr., Jewson LG. The effectiveness of subgingival scaling and root planing. II. Clinical responses related to residual calculus. Journal of periodontology. 1990; 61:915.

9. Mombelli A. Antimicrobial advances in treating periodontal diseases. Frontiers of oral biology. 2012; 15:133-48.

10.Sanz M, Teughels W, Group AoEWoP. Innovations in non-surgical periodontal therapy: Consensus Report of the Sixth European Workshop on Periodontology. Journal of clinical periodontology. 2008; 35:3-7.

11.Socransky SS, Haffajee AD. Dental biofilms: difficult therapeutic targets. Periodontology 2000. 2002; 28:12-55.

12.Saglam M, Kantarci A, Dundar N, Hakki SS. Clinical and biochemical effects of diode laser as an adjunct to nonsurgical treatment of chronic periodontitis: a randomized, controlled clinical trial. Lasers in medical science. 2014; 29:37-46.

13. Aoki A, Sasaki KM, Watanabe H, Ishikawa I. Lasers in nonsurgical periodontal therapy. Periodontology 2000. 2004; 36:59-97.

14.Ishikawa I, Aoki A, Takasaki AA, Mizutani K, Sasaki KM, Izumi Y. Application of lasers in periodontics: true innovation or myth? Periodontology 2000. 2009; 50:90-126.

15. Yiğit ŞB GM. Periodontolojide lazer. Selçuk Üniversitesi Dişhekimliği Fakültesi Dergisi. 2007; 16:67-73. 
16. Research S, Therapy Committee of the American Academy of P. Lasers in periodontics. Journal of periodontology. 2002; 73:1231-9.

17. Moritz A, Gutknecht N, Doertbudak O, Goharkhay K, Schoop U, Schauer P, et al. Bacterial reduction in periodontal pockets through irradiation with a diode laser: a pilot study. Journal of clinical laser medicine \& surgery. 1997; 15:33-7.

18.Harris DM, Yessik M. Therapeutic ratio quantifies laser antisepsis: ablation of Porphyromonas gingivalis with dental lasers. Lasers in surgery and medicine. 2004; 35:20613.

19. Moritz A, Schoop U, Goharkhay K, Schauer $\mathrm{P}$, Doertbudak O, Wernisch J, et al. Treatment of periodontal pockets with a diode laser. Lasers in surgery and medicine. 1998; 22:302-11.

20.Shimura $M$, Watanabe $S$, Iwakura $M$, Oshikiri Y, Kusumoto M, Ikawa K, et al. Correlation between measurements using a new halitosis monitor and organoleptic assessment. Journal of periodontology. 1997; 68:1182-5.

21. Quirynen M, Avontroodt P, Soers C, Zhao H, Pauwels M, van Steenberghe D. Impact of tongue cleansers on microbial load and taste. Journal of clinical periodontology. 2004; 31:50610.

22. Tangerman A, Winkel EG. Intra- and extraoral halitosis: finding of a new form of extra-oral blood-borne halitosis caused by dimethyl sulphide. Journal of clinical periodontology. 2007; 34:748-55.

23. Morita M, Wang HL. Association between oral malodor and adult periodontitis: a review. Journal of clinical periodontology. 2001; 28:8139.

24. Bollen CM, Beikler T. Halitosis: the multidisciplinary approach. International journal of oral science. 2012; 4:55-63.

25. Amir E, Shimonov R, Rosenberg M. Halitosis in children. The Journal of pediatrics. 1999; 134:338-43.

26. Marocchio LS, Junior DS, de Sousa SC, Fabre RF, Raitz R. Multifocal diffuse oral melanoacanthoma: a case report. Journal of oral science. 2009; 51:463-6.

27.Scully C, Greenman J. Halitology (breath odour: aetiopathogenesis and management). Oral diseases. 2012; 18:333-45.

28.TAŞDOĞAN BE GY. Halitozis ve Helikobakter pilori. . Güncel Gastroenteroloji Dergisi. 2015; 15.

29. Torresyap G, Haffajee AD, Uzel NG, Socransky SS. Relationship between periodontal pocket sulfide levels and subgingival species. Journal of clinical periodontology. 2003; 30:1003-10.

30.Sanz M, Roldan S, Herrera D. Fundamentals of breath malodour. The journal of contemporary dental practice. 2001; 2:1-17.

31. Yaegaki K, Sanada K. Volatile sulfur compounds in mouth air from clinically healthy subjects and patients with periodontal disease. Journal of periodontal research. 1992; 27:233-8.

32. Yaegaki K, Coil JM. Examination, classification, and treatment of halitosis; clinical perspectives. Journal. 2000; 66:257-61.

33.Johnson PW, Yaegaki K, Tonzetich J. Effect of volatile thiol compounds on protein metabolism by human gingival fibroblasts. Journal of periodontal research. 1992; 27:553-61.

34.Johnson P, Yaegaki K, Tonzetich J. Effect of methyl mercaptan on synthesis and degradation of collagen. Journal of periodontal research. 1996; 31:323-9.

35.Calenic $B$, Yaegaki $K$, Murata $T$, Imai $T$, Aoyama I, Sato T, et al. Oral malodorous compound triggers mitochondrial-dependent apoptosis and causes genomic DNA damage in human gingival epithelial cells. Journal of periodontal research. 2010; 45:31-7.

36. Yaegaki K, Qian W, Murata T, Imai T, Sato $\mathrm{T}$, Tanaka $\mathrm{T}$, et al. Oral malodorous compound causes apoptosis and genomic DNA damage in human gingival fibroblasts. Journal of periodontal research. 2008; 43:391-9.

37.Ng W, Tonzetich J. Effect of hydrogen sulfide and methyl mercaptan on the permeability of oral mucosa. Journal of dental research. 1984; 63:994-7. 
38. Rosenberg M, Kulkarni GV, Bosy A, McCulloch CA. Reproducibility and sensitivity of oral malodor measurements with a portable sulphide monitor. Journal of dental research. 1991; 70:1436-40.

39.Kim DJ, Lee JY, Kho HS, Chung JW, Park HK, Kim YK. A new organoleptic testing method for evaluating halitosis. Journal of periodontology. 2009; 80:93-7.

40. Murata T, Rahardjo A, Fujiyama Y, Yamaga T, Hanada M, Yaegaki K, et al. Development of a compact and simple gas chromatography for oral malodor measurement. Journal of periodontology. 2006; 77:1142-7.

41.Rosenberg M, McCulloch CA. Measurement of oral malodor: current methods and future prospects. Journal of periodontology. 1992; 63:776-82.

42.Kizhner V, Xu D, Krespi YP. A new tool measuring oral malodor quality of life. European archives of oto-rhino-laryngology : official journal of the European Federation of OtoRhino-Laryngological Societies. 2011; 268:1227-32.

43. Rosenberg M. Bad breath, diagnosis and treatment. University of Toronto dental journal. 1990; 3:7-11.

44.Donaldson AC, Riggio MP, Rolph HJ, Bagg J, Hodge PJ. Clinical examination of subjects with halitosis. Oral diseases. 2007; 13:63-70.

45. Furne J, Majerus G, Lenton P, Springfield J, Levitt DG, Levitt MD. Comparison of volatile sulfur compound concentrations measured with a sulfide detector vs. gas chromatography. Journal of dental research. 2002; 81:140-3.

46. Rosenberg M. Bad breath and periodontal disease: how related are they? Journal of clinical periodontology. 2006; 33:29-30.

47.Raangs GC, Winkel EG, van Winkelhoff AJ. In vitro antimicrobial effects of two antihalitosis mouth rinses on oral pathogens and human tongue microbiota. International journal of dental hygiene. 2013; 11:203-7.

48. Tolentino Ede S, Chinellato LE, Tarzia O. Saliva and tongue coating $\mathrm{pH}$ before and after use of mouthwashes and relationship with parameters of halitosis. Journal of applied oral science : revista FOB. 2011; 19:90-4.

49. Wainwright $M$. Photodynamic antimicrobial chemotherapy (PACT). The Journal of antimicrobial chemotherapy. 1998; 42:13-28.

50.Saad S, Greenman J, Shaw H. Comparative effects of various commercially available mouthrinse formulations on oral malodor. Oral diseases. 2011; 17:180-6.

51.Quirynen M, Mongardini C, van Steenberghe D. The effect of a 1-stage full-mouth disinfection on oral malodor and microbial colonization of the tongue in periodontitis. A pilot study. Journal of periodontology. 1998; 69:374-82.

52.Karlsson MR, Diogo Lofgren CI, Jansson HM. The effect of laser therapy as an adjunct to non-surgical periodontal treatment in subjects with chronic periodontitis: a systematic review. Journal of periodontology. 2008; 79:2021-8.

53. Cobb CM. Lasers in periodontics: a review of the literature. Journal of periodontology. 2006; 77:545-64.

54. Slot DE, Kranendonk AA, Paraskevas S, Van der Weijden F. The effect of a pulsed Nd:YAG laser in non-surgical periodontal therapy. Journal of periodontology. 2009; 80:1041-56.

55.Miyazaki A, Yamaguchi T, Nishikata J, Okuda K, Suda S, Orima K, et al. Effects of $\mathrm{Nd}: Y A G$ and $\mathrm{CO} 2$ laser treatment and ultrasonic scaling on periodontal pockets of chronic periodontitis patients. Journal of periodontology. 2003; 74:175-80.

56. De Micheli G, de Andrade AK, Alves VT, Seto M, Pannuti CM, Cai S. Efficacy of high intensity diode laser as an adjunct to non-surgical periodontal treatment: a randomized controlled trial. Lasers in medical science. 2011; 26:43-8.

57. Ambrosini P, Miller N, Briancon $S$, Gallina $S$, Penaud J. Clinical and microbiological evaluation of the effectiveness of the Nd:Yap laser for the initial treatment of adult periodontitis. A randomized controlled study. Journal of clinical periodontology. 2005; 32:6706.

58. Aykol G, Baser U, Maden I, Kazak Z, Onan $\mathrm{U}$, Tanrikulu-Kucuk S, et al. The effect of low- 
level laser therapy as an adjunct to non-surgical periodontal treatment. Journal of periodontology. 2011; 82:481-8.

59.Kreisler M, Al Haj H, d'Hoedt B. Clinical efficacy of semiconductor laser application as an adjunct to conventional scaling and root planing. Lasers in surgery and medicine. 2005; 37:350-5. 60.Qadri T, Miranda L, Tuner J, Gustafsson A. The short-term effects of low-level lasers as adjunct therapy in the treatment of periodontal inflammation. Journal of clinical periodontology. 2005; 32:714-9.

61.Ustun K, Erciyas K, Sezer U, Senyurt SZ, Gundogar H, Ustun $\mathrm{O}$, et al. Clinical and biochemical effects of $810 \mathrm{~nm}$ diode laser as an adjunct to periodontal therapy: a randomized split-mouth clinical trial. Photomedicine and laser surgery. 2014; 32:61-6.

62.Loesche WJ, Kazor C. Microbiology and treatment of halitosis. Periodontology 2000. 2002; 28:256-79.

63. Miyazaki H, Sakao S, Katoh Y, Takehara T. Correlation between volatile sulphur compounds and certain oral health measurements in the general population. Journal of periodontology. 1995; 66:679-84.

64. Soder B, Johansson B, Soder PO. The relation between foetor ex ore, oral hygiene and periodontal disease. Swedish dental journal. 2000; 24:73-82.

65.Proietti MC, Reisser J, Marins LF, Marcovaldi MA, Soares LS, Monteiro DS, et al.
Hawksbill $\mathrm{x}$ loggerhead sea turtle hybrids at Bahia, Brazil: where do their offspring go? PeerJ. 2014; 2:e255.

66.Persson S, Edlund MB, Claesson R, Carlsson J. The formation of hydrogen sulfide and methyl mercaptan by oral bacteria. Oral microbiology and immunology. 1990; 5:195-201.

67.Pham TA, Ueno M, Zaitsu T, Takehara S, Shinada K, Lam PH, et al. Clinical trial of oral malodor treatment in patients with periodontal diseases. Journal of periodontal research. 2011; 46:722-9.

68. Morita M, Wang HL. Relationship of sulcular sulfide level to severity of periodontal disease and BANA test. Journal of periodontology. 2001; 72:74-8.

69. Coli JM, Tonzetich J. Characterization of volatile sulphur compounds production at individual gingival crevicular sites in humans. The Journal of clinical dentistry. 1992; 3:97-103.

\section{Correspondence Author}

Dr. Mükerrem Hatipoğlu.

Akdeniz University

Faculty of Dentistry

Department of Periodontology.

07058 Antalya.

Phone: 05418838309

E-mail:mukerremhatipoglu@hotmail.com 